\title{
PENGARUH TEHNIK MODERN WOUND DRESSING TERHADAP PROSES PENYEMBUHAN LUKA ULKUS DIABETIKUM PADA PASIEN DIABETES MELLITUS DI KLINIK WOUND \& FOOTCARE RSUD AL IHSAN PROVINSI JAWA BARAT
}

\author{
Sadaukur Barus ${ }^{1 *}$, Briefman Tampubolon ${ }^{2}$, Siti Aminah ${ }^{3}$ \\ ${ }^{1-3}$ Program Pendidikan Ners STIKes Budi Luhur Cimahi: \\ Email Korespondensi: sada.love,mumuh@gmail.com
}

Disubmit: 24 Januari 2022 Diterima: 27 Januari 2022 Diterbitkan: 02 Februari 2022 DOI: https://doi.org/10.33024/mnj.v5i2.5913

\begin{abstract}
THE IMPACTS OF MODERN WOUND DRESSING TOWARD DIABETES ULCUS WOUND RECOVERY ON DIABETES MELLITUS PATIENTS IN WOUND AND FOOT CARE CLINIC AT AL-IHSAN PUBLIC HOSPITAL, WEST JAVA PROVINCE
\end{abstract}

Backgroud: Diabetes mellitus (DM) is a disease signed by the increasing of blood glucose rate. DM can cause some complications if it is not treated well. One of the complications is such as diabetic ulcus. It is categorized chronic wound that being hard to be treated and needed appropriate wound care as using modern wound dressing technique.

Purpose: of this study is to identify the impacts of modern wound dressing toward diabetes ulcus wound recovery on diabetes mellitus patients in wound and foot care clinic at Al-Ihsan Hospital, West Java.

Method Queasy experimental designs with one group pretest posttest, there is no control group. Wound care treatmen with modern dressing techniques before and after the intervention was observed using the BWAT(Bates Wound Assessment Tool) assessment sheet which was carried out 3 times. The sampling technique in this study used a sampling metohod with non-random sampling (non-probability sampling) with a purposive sampling technigue and responden in the study 13.

Results: Based on the Paired T Test, it was obtained $p_{\text {value }} 0,000$ and $p_{\text {value }}<a$ $(0,05)$ so that it can be concluded Ho was rejected. It means that there is the significant impacts of modern wound dressing technique with the recovery process of diabetes ulcus wound on diabetes mellitus patients in wound and foot care clinic at Al-Ihsan Public Hospital, West Java province n 2018.

Conclusion: The result of this study for medical surgery nurses are hoped to be able to implement modern wound dressing technique by attending the modern wound care training.

Keywords: Diabetes mellitus, diabetic ulcus, dressing modern technique, wound care process 
INTISARI: PENGARUH TEHNIK MODERN WOUND DRESSING TERHADAP PROSES PENYEMBUHAN LUKA ULKUS DIABETIKUM PADA PASIEN DIABETES MELLITUS DI KLINIK WOUND \& FOOTCARE RSUD AL IHSAN PROVINSI JAWA BARAT

Pendahuluan: Diabetes Mellitus (DM) merupakan penyakit yang ditandai dengan adanya kenaikan kadar gula darah. DM jika tidak ditangani dengan baik dapat mengakibatkan timbulnya beberapa komplikasi salah satunya ulkus diabetikum. Ulkus diabetikum tergolong luka kronik yang sulit sembuh dan memerlukan perawatan luka yang tepat, yaitu dengan menggunakan tehnik modern wound dressing.

Tujuan: Penelitian ini bertujuan untuk menganalisis pengaruh tehnik modern wound dressing terhadap proses penyembuhan luka ulkus diabetikum pada pasien diabetes mellitus di Klinik Wound \& Foot Care RSUD Al-Ihsan Provinsi Jawa Barat.

Metode: Desain penelitian quasy experimental designs dengan rancangan One Group Pretest Posttest dalam rancangan tidak ada kelompok kontrol. Perlakuan wound care dengan tehnik modern dressing sebelum dan sesudah intervensi dilakukan obsevasi mengunakan lembaran penilaian BWAT (Bates Wound Assement Tool) yang dilakukan 3 kali kunjungan. Tehnik pengambilan sampel dalam penelitian ini menggunakan metode sampling dengan pengambilan non random (Non probability Sampling) dengan teknik purposive sampling. Responden penelitian sebanyak 13 .

Hasil Penelitian: Berdasarkan hasil uji Paired T Test, diperoleh nilai $P$ Value yaitu 0,000 , Karena nilai $p<a(0,05)$ maka disimpulkan Ho ditolak. Bahwa ada pengaruh yang bermakna antara tehnik modern wound dressing dengan proses penyembuhan luka ulkus diabetikum pada pasien diabetes mellitus di Klinik Wound \& Footcare Rsud Al Ihsan Provinsi Jawa barat tahun 2018.

Kesimpulan: Dalam memberikan asuhan keperawatan pada pasien luka ulkus diabetikum, dapat mengaplikasikan perawatan luka dengan tehnik modern wound dressing dengan mengikuti pelatihan perawatan luka modern.

Keywords: Diabetes mellitus, ulkus diabetikum, Tehnik Modern Dressing, Proses penyembuhan luka.

\section{PENDAHULUAN}

Diabetes Melitus merupakan penyakit yang ditandai dengan kenaikan kadar gula darah (hyperglycemia) kronik yang dapat menyerang banyak orang dari semua lapisan masyarakat (Hasnah, 2009). Jumlah penderita diabetes mellitus dari tahun ke tahun terus mengalami peningkatan, perubahan gaya hidup menjadi salah satu penyebab tingginya angka penderita diabetes mellitus di negara-negara berkembang. WHO memperkirakan ditahun 2025 penderita diabetes usia diatas 20 tahun adalah 300 juta orang dan mengalami peningkatan dua kali lipat dari tahun 2000 yaitu 150 juta orang (Sudoyo. 2009). Laporan statistik dari International Diabetes Federation (2015), menunjukan bahwa, kasus diabetes mellitus sebesar $8,3 \%$ dari seluruh penduduk dunia atau sekitar 387 juta kasus dan mengalami peningkatan setiap tahunnya hingga $3 \%$.

Menurut data dari Riset Kesehatan Dasar (2013) Indonesia merupakan negara ke-7 penderita diabetes mellitus terbesar di dunia dengan 8,5 juta penderita pada kategori dewasa. Diperkirakan prevalensi diabetes mellitus akan terus meningkat dengan perubahan 
gaya hidup dan pola konsumsi makanan. Prevalensi diabetes mellitus cenderung lebih tinggi bagi penderita yang tinggal di perkotaan dibandingkan dengan di pedesaan dan prevalensi penderita diabetes mellitus pada jenis kelamin laki-laki dengan perempuan relatif sama, dimana terjadi peningkatan prevalensi penyakit sesuai dengan pertambahan umur. Dan pada tahun 2030 di Indonesia dipresdiksi kasus diabetes mellitus terus meningkat hingga 21,3 juta jiwa.

RSUD AL Ihsan merupakan Rumah sakit tipe $B$ yang terus berkembang dalam melakukan pelayanan kesehatannya, salah satunya dengan dikembangkannya Klinik Wound \& Foot Care, diimana Klinik Wound \& Foot Care ini menyediakan perawatan luka dan dilakukan oleh perawat yang telah berkompeten. Angka kunjungan pasien diabetes mellitus secara umum di klinik RSUD Al Ihsan Provinsi Jawa Barat terbilang cukup tinggi yaitu terdapat 17.974 kunjungan pada tahun 2017. Angka kunjungan pasien diabetes mellitus dengan luka ulkus diabetikum di Klinik Wound \& Foot Care RSUD Al Ihsan Provinsi Jawa Barat pada tahun 2017 pun terbilang cukup tinggi yang akan di tunjukan pada tabel di bawah ini :

Tabel 1.Kunjungan Pasien dengan Ulkus Diabetikum di Klinik Wound \& Foot Care RSUD Al Ihsan Provinsi Jawa Barat 2017

\begin{tabular}{clc}
\hline No & \multicolumn{1}{c}{ Nama Penyakit } & Kunjungan \\
\hline 1. & Januari & 32 \\
2. & Febuari & 54 \\
3. & Maret & 97 \\
4. & April & 68 \\
5. & Mei & 67 \\
6 & Juni & 70 \\
7 & Juli & 96 \\
8 & Agustus & 111 \\
9 & September & 122 \\
10 & Oktober & 128 \\
11 & September & 106 \\
12 & Desember & 112 \\
\hline \multicolumn{2}{c}{ Jumlah } & 1063 \\
\hline
\end{tabular}

Berdasarkan tabel 1. diatas didapatkan data kunjungan pasien dengan luka ulkus diabetikum di Klinik Wound \& Foot Care RSUD Al Ihsan Provinsi Jawa Barat pada tahun 2017 sebanyak 1063 kunjungan.

Hasil studi pendahuluan yang dilakukan oleh peneliti di Klinik Wound \& Foot Care RSUD Al Ihsan Provinsi Jawa Barat pada tanggal 15 Februari 2018 terdapat 10 pasien dengan luka ulkus diabetikum yang menjalani perawatan luka. Dengan melakukan tehnik wawancara didapatkan hasil dimana semua pasien mengatakan datang ke Klinik Wound \& Foot Care Rumah Sakit Umum Daerah Al Ihsan Provinsi Jawa Barat karena ingin melakukan perawatan luka diabetesnya. Dan pada pemeriksaan luka ulkus diabetikum pada 10 pasien tersebut 
didapatkan hasil 6 pasien memiliki luka diabetes dengan grade 3 ditandai dengan adanya abses pada luka dan 4 pasien memiliki luka diabetes dengan grade 2 ditandai dengan adanya kerusakan kulit mencapai otot.

Diabetes mellitus sering disebut sebagai the great imitator (menyerupai penyakit lain) karena penyakit ini dapat mengenai semua organ tubuh dan menimbulkan berbagai macam keluhan dan gejala yang sangat bervariasi. Diabetes mellitus jika tidak ditangani dengan baik akan mengakibatkan timbulnya beberapa komplikasi bersama-sama atau terdapat satu masalah yang mendominasi seperti kelainan vaskuler, retinopati, nefropati diabetik, neuropati diabetik dan ulkus diabetik (Poerwanto, 2012).

Neuropati diabetik merupakan komplikasi yang paling sering ditemukan pada pasien diabetes mellitus. Neuropati pada diabetes mellitus mengacu pada sekelompok penyakit yang menyerang semua tipe saraf. Neuropati diabetik berawal dari hiperglikemia yang berkepanjangan. Risiko yang dihadapi pasien diabetes mellitus dengan neuropati diabetik yaitu adanya ulkus diabetik yang tidak sembuh- sembuh dan amputasi jari atau kaki (Subekti, 2009). Dan apabila ulkus diabetikum ini dikonsulkan ke dokter bedah kebanyakan dari mereka selalu mengalami tidakan amputasi.

Ulkus diabetik merupakan salah satu komplikasi pada pasien diabetes mellitus dan tergolong luka kronik yang sulit sembuh. Kerusakan jaringan yang terjadi pada ulkus diabetik diakibatkan oleh gangguan neurologis (neuropati) dan vaskuler. Gangguan tersebut tidak secara langsung menyebabkan ulkus diabetik, namun diawali dengan mekanisme penurunan sensasi terhadap nyeri, atrofi otot, pembentukan kalus, penurunan ketajaman penglihatan dan penurunan aliran darah yang membawa oksigen dan nutrisi ke jaringan. Perubahan-perubahan ini dapat terjadi dalam jangka waktu kira-kira 15 tahun bila kondisi hiperglikemia tidak terkontrol (Smeltzer \& Bare. 2010).

Penatalaksanaan Ulkus diabetik memerlukan perawatan luka yang tepat. Saat ini, tekhnik perawatan luka (wound care) telah banyak mengalami perkembangan, dimana perawatan luka telah menggunakan balutan yang lebih modern. Prinsip dari menejemen perawatan luka modern adalah mempertahankan dan menjaga lingkungan luka tetap lembab untuk memperbaiki proses penyembuhan luka, mempertahankan kehilangan cairan jaringan dan kematian sel (Ismail. 2009).

Wound care dengan menggunakan moisture balance dikenal sebagai metode modern dressing yang memakai bahan-bahan pembalut yang lebih modern dan topical therapy yang mempunyai karakteristik dan keunggulan masing-masing sesuai dengan kondisi luka pasien (Ismail, 2008). Menurut Sing (2011) menyatakan 60\% klien yang melakukan perawatan luka dengan modern dressing menunjukkan bersih dari organisme secara penuh dalam dua minggu, dan sekitar $90 \%$ dalam empat minggu meskipun tidak sepenuhnya menunjukkan bersih dari organisme di akhir minggu ke-empat.

Hal ini sesuai dengan penelitian yang dilakukan oleh Nontji, dkk (2015) tentang teknik Perawatan Luka Modern dan Konvensional Terhadap Kadar Interleukin 1 dan Interleukin 6 Pasien Luka Diabetik mendapatkan hasil bahwa adanya pengaruh Perawatan Luka Modern dan Konvensional Terhadap Kadar Interleukin 1 dan Interleukin 6 
Pasien Luka Diabetik. Berlainan dengan penelitian yang telah dilakukan oleh Haryati, dkk (2009) di Rumah Sakit dr. Saiful Answar Malang dan Rumah Sakit Ngudi Waluyo Blitar tentang Penggunaan Balutan Modern Memperbaiki Proses Penyembuhan Luka Diabetik mendapatkan hasil bahwa tidak ada pengaruh Penggunaan Balutan Modern Memperbaiki Proses Penyembuhan Luka Diabetik.

Rumusan masalah dalam penelitian ini adalah "Adakah pengaruh teknik modern dressing terhadap proses penyembuhan luka ulkus diabetikum pada pasien diabetes mellitus di Klinik Wound \& Foot Care RSUD Al Ihsan Provinsi Jawa Barat"?

Tujuan umum penelitian adalah untuk diketahuinya pengaruh tehnik modern dressing terhadap proses penyembuhan luka ulkus diabetikum pada pasien diabetes mellitus di
Klinik Wound \& Foot Care RSUD AlIhsan Provinsi Jawa Barat.

\section{METODE PENELITIAN}

Rancangan

penelitian

menggunakan metode penelitian quasy experimental designs dengan rancangan One Group PretestPosttest, dalam rancangan tidak ada kelompok kontrol. Peneliti memberikan perlakuan wound care dengan tehnik modern dressing dengan sebelum dan sesudah intervensi dilakukan obsevasi mengunakan lembaran penilaian BWAT (Bates Wound Assement Tool) yang dilakukan 3 kali kunjungan. Tehnik pengambilan sampel dalam penelitian ini menggunakan metode sampling dengan pengambilan non random (Non probability Sampling) dengan teknik purposive sampling, dan penelitian ini ada 13 responden.

HASIL

1. Analisa Univariat

Tabel 1. Distribusi luka ulkus diabetikum pada pasien Diabetes Mellitus sebelum dan setelah dilakukan perawatan luka dengan tehnik Modern wound dressing

\begin{tabular}{ccccc}
\hline \multirow{2}{*}{$\begin{array}{c}\text { Katagori } \\
\text { Luka }\end{array}$} & \multicolumn{2}{c}{$\begin{array}{c}\text { Sebelum modern } \\
\text { wound }\end{array}$} & $\begin{array}{c}\text { Sressing } \\
\text { wound dressing }\end{array}$ \\
\cline { 2 - 5 } & $\begin{array}{c}\text { Frekuensi } \\
\text { (f) }\end{array}$ & $\begin{array}{c}\text { Prosentase } \\
\text { (\%) }\end{array}$ & $\begin{array}{c}\text { Frekuensi } \\
\text { (f) }\end{array}$ & $\begin{array}{c}\text { Prosentase } \\
\mathbf{( \% )}\end{array}$ \\
\hline Jaringan sehat & 0 & 0 & 0 & 0 \\
Regenerasi luka & 11 & 84,6 & 13 & 100 \\
Degenerasi luka & 2 & 15,3 & 0 & 0 \\
\hline Total & 13 & 100 & 13 & 100 \\
& & & &
\end{tabular}

Sumber : Data Primer (2018)

Berdasarkan tabel 1. diatas

diketahui bahwa dari 13

responden diabetes mellitus

dengan ulkus diabetikum

sebelum dilakukan

perawatan luka dengan

modern wound dressing sebagian besar yaitu 11 orang $(84,6 \%)$ berada pada katagori regenerasi luka, dan sebagian kecil lainnya yaitu 2 orang $(15,3 \%)$ berada pada katagori degenerasi luka. Dan gambaran luka ulkus 
diabetikum setelah

dilakukan perawatan luka

dengan tehnik modern

wound dressing semua responden berada pada katagori regenerasi luka yaitu 13 orang $(100 \%)$.

\section{Analisa Bivariat}

Tabel 2. Distribusi Uji Normalitas Variabel Luka Ulkus diabetikum pada pasien diabetes mellitus sebelum dan sestelah dilakukan perawatan luka dengan tehnik modern wound dressing

\begin{tabular}{lccc}
\hline \multirow{2}{*}{ Katagori luka } & \multicolumn{3}{c}{ Hasil } \\
\cline { 2 - 4 } & Skewness & Standar Variabel \\
\cline { 2 - 4 } & 0,828 & 0,616 & 1,344 (Normal) \\
\hline Pretest & 0,109 & 0,616 & 0,176 (Normal) \\
Posttest & 2018 &
\end{tabular}

Sumber : Data Primer 2018

Hasil perbandingan nilai skewness dengan standar Error didapatkan hasil nilai katagori ulkus diabetikum pada pasien dibetes melitus. Variabel sebelum (Pretest) setelah nilai skewnes dibagi nilai standar error didapatkan hasil nilai Skewness/SE sebelum (Pretest) 1,344 maka data dinyatakan berdistribusi normal karena nilai skewness sebelum (Pretest) berada diantara nilai -2 sama dengan 2 , sedangkan nilai variabel sesudah (Posttest) setelah nilai skewness dibagi nilai Standar Error didapatkan hasil nilai Skewness/SE sesudah (Posttest) 0,176 maka data dinyatakan berdistribusi normal karena nilai skewnes/SE sesudah (Posttest) berada diantara nilai -2 sama dengan 2 , sehingga uji yang digunakan yaitu dengan menggunakan statistik parametrik.

3. Pengaruh tehnik modern wound dressing terhadap proses penyembuhan luka ulkus diabetikum pada pasien diabetes melitus

Tabel 3. Distribusi rata-rata skor luka sebelum dan setelah dilakukan perawatan luka dengan tehnik Modern wound dressing terhadap proses penyembuhan luka ulkus diabetikum pada pasien diabetes mellitus

\begin{tabular}{rccccc}
\hline Variable & Mean & SD & SE Mean & $p V$ & $\mathbf{N}$ \\
\hline Luka sebelum & 46,85 & 8,454 & 2,345 & 0,000 & 13 \\
Luka sesudah & 33,77 & 11,469 & 3,231 & & 13 \\
\hline
\end{tabular}

Sumber : dataPrimer (2018)

Berdasarkan pada tabel 3. Variabel luka sebelum dilakukan perawatan luka dengan tehnik modern wound dressing diperoleh rata-rata nilai Mean $(46,85)$, nilai Standar Deviasi $(8,454)$, nilai Standar Error Mean $(2,345)$. Dan setelah dilakukan perawatan luka dengan 
tehnik modern wound dressing diperoleh rata-rata nilai Mean $(33,77)$, nilai standar Deviasi $(11,469)$, nilai standar Error Mean (3,231). Berdasarkan uji statistik Paired $T$ Test, diperoleh nilai signifikan $\mathrm{p}=$ 0,000 . Karena nilai $p<a$ $(0,05)$ maka disimpulkan Ho ditolak. Dengan demikian

\section{PEMBAHASAN}

\section{Gambaran luka ulkus diabetikum sebelum dilakukan perawatan luka dengan Modern wound dressing}

Hasil penelitian yang telah dilakukan terhadap 13 responden sebelum dilakukan perawatan luka dengan modern wound dressing dengan pendekatan BWAT sebagian besar yaitu 11 orang $(84,6 \%)$ berada pada katagori regenerasi luka dengan nilai luka diantara 13-59, dan sebagian kecil lainnya yaitu 2 orang $(15,3 \%)$ berada pada katagori degenerasi luka dengan nilai luka $\geq 60$. Dari hasil pengkajian terdapat beberapa faktor yang menjadi pencetus terjadinya ulkus diabetikum pada pasien diabetes mellitus diantaranya: Jenis kelamin, usia,kebiasaan

merokok,dan status gizi. Hasil penelitian diketahui bahwa 61,5\% pasien ulkus diabetikum berjenis kelamin wanita. Hal ini sesuai dengan penelitian Ferawati (2014), yang menunjukan bahwa jenis kelamin perempuan berisiko terhadap terjadinya ulkus diabetikum. Hal ini disebabkan karena adanya perubahan hormonal pada perempuan yang memasuki masa menopause. Hasil penelitian serupa juga pernah dilakukan oleh Purwanti (2013) yang menyatakan bahwa terdapat $64,7 \%$ responden berjenis kelamin perempuan yang menderita diabetes mellitus maka dapat disimpulkan bahwa ada pengaruh yang bermakna antara tehnik modern wound dressing dengan proses penyembuhan luka ulkus diabetikum pada pasien diabetes mellitus di Klinik Wound \& Footcare RSUD Al Ihsan Provinsi Jawa barat tahun 2018.

dibandingkan jenis kelamin laki-laki. Menurut peneliti, jenis kelamin merupakan salah satu faktor resiko terjadinya ulkus diabetikum khususnya pada wanita.

Usia merupakan faktor resiko selanjutnya yang menjadi penyebab terjadinya ulkus diabetikum. Berdasarkan hasil penelitian ini didapatkan rentang usia antara 4858 tahun. Rentang usia tersebut masuk dalam katagori usia lanjut awal. Usia lanjut beresiko terjadinya ulkus diabetikum,karena pada usia lanjut fungsi tubuh secara fisiologis menurun, hal ini disebabkan karena penurunan sekresi atau resistensi insulin sehingga kemampuan fungsi tubuh terhadap pengendalian glukosa darah yang tinggi kurang optimal (Ferawati,2014).

Selain faktor jenis kelamin dan usia salah satu pencetus ulkus diabetikum adalah kebiasaan merokok. Pasien ulkus diabetikum didalam penelitian ini, memiliki kebiasaan merokok yang lebih sering sebelum terkena ulkus diabetikum. Menurut Schwart (2000), pasien diabetes mellitus yang memiliki riwayat atau kebiasaan merokok beresiko 10-16 kali lebih besar terjadinya peripheral arterial desease merupakan penyakit akibat sumbatan aliran darah dari atau ke jaringan organ.

Dan faktor selanjutnya yaitu status gizi pasien ulkus diabetikum berdasarkan perhitungan indeks 
massa tubuh (IMT). Berdasarkan hasil penelitian, hampir separuhnya lebih pasien ulkus diabetikum memiliki berat badan normal. Menurut Arief (2010), kelebihan berat badan hingga kegemukan jelas sangat beresiko bagi kesehatan dan memperbesar timbulnya penyakit,terutama sekali pada pasien diabetes mellitus kelebihan berat badan membuat tubuh rentan penyakit karena lemak yang mengumpul telah menghambat peredaran darah dan asupan gizi yang diperlukan tubuh. Teori tersebut tidak sesuai dengan hasil penelitian, karena separuh responden yang terkena ulkus diabetikum memiliki berat badan yang normal. Menurut pendapat peneliti bahwa kegemukan akan menyebabkan tidak lancarnya produksi insulin normal dalam tubuh, sehingga pada pasien diabetes mellitus dengan berat badan berlebih memiliki resiko terkena ulkus diabetikum.

Gambaran luka ulkus diabetikum setelah dilakukan perawatan luka dengan Modern wound dressing

Hasil penelitian setelah dilakukan perawatan luka dengan tehnik modern wound dressing diperoleh bahwa seluruh responden berada pada katagori Regenerasi Luka (Nilai Luka 13-60) yaitu 13 orang (100\%). Modern wound dressing adalah teknik perawatan luka dengan menciptakan kondisi lembab pada luka sehingga dapat membantu proses epitelisasi dan penyembuhan luka, menggunakan balutan semi occlusive, full occlusive dan impermeable dressing berdasarkan pertimbangan biaya (cost), kenyamanan (comfort), keamanan (safety) (Suryo, 2009). Proses penyembuhan pasien luka ulkus diabetikum diabetes mellitus setelah dilakukan perawatan luka dengan menggunakan tehnik modern wound dressing memperoleh hasil yang optimal.

\section{Pengaruh tehnik modern wound dressing terhadap proses penyembuhan luka ulkus diabetikum}

Hasil penelitian yang didapatkan dari 13 responden dengan ulkus diabetikum diperoleh hasil bahwa ada perubahan katagori luka sebelum dan sesudah perawatan luka dengan tehnik modern wound dressing. Sebelum dilakukan perawatan luka dengan tehnik modern wound dressing terdapat 11 orang $(84,6 \%)$ berada pada katagori regenerasi luka (Nilai luka 13-59), dan sebagian kecil lainnya yaitu 2 orang $(15 \%)$ berada pada katagori Degenerasi luka (Nilai Luka $\geq 60$ ). Setelah dilakukan perawatan luka sebanyak 3 kali kujungan dengan tehnik modern wound dressing diperoleh hasil bahwa seluruh responden yaitu 13 orang (100\%) berada pada katagori Regenerasi Luka (Nilai Luka 13-60).

Berdasarkan hasil uji Paired T Test, diperoleh nilai $P$ Value yaitu 0,000 , Karena nilai $p<a(0,05)$ maka disimpulkan Ho ditolak. Dengan demikian maka dapat disimpulkan bahwa ada pengaruh yang bermakna antara tehnik modern wound dressing dengan proses penyembuhan luka ulkus diabetikum pada pasien diabetes mellitus di Klinik Wound \& Footcare RSUD Al Ihsan Provinsi Jawa barat tahun 2018). Perawatan luka dengan tehnik modern wound dressing prinsipnya kelembaban yang seimbang, dapat mempercepat fibrinolisis dimana fibrin yang terbentuk pada luka kronis dapat dihilangkan lebih cepat oleh netrofil dan sel endotel. Selain itu, mempercepat angiogenesis dimana dalam keadaan hipoksia pada perawatan luka tertutup akan 
merangsang lebih pembentukan pembuluh darah dengan lebih cepat. Selanjutnya menurunkan resiko infeksi dengan hasil kejadian infeksi ternyata relatif lebih rendah jika dibandingkan dengan perawatan kering. Alasan lain yaitu mempercepat pembentukan growth factor karena, berperan pada proses penyembuhan luka untuk membentuk stratum corneum dan angiogenesis, dimana produksi komponen tersebut lebih cepat terbentuk dalam lingkungan yang lembab. Dan alasan lain yaitu mempercepat terjadinya pembentukan sel aktif, dimana pada keadaan lembab, invasi netrofil yang diikuti oleh makrofag, monosit dan limfosit ke daerah luka berfungsi lebih dini.

Pada dasarnya prinsip pemilihan balutan yang akan digunakan untuk membalut luka harus memenuhi kaidah-kaidah seperti kapasitas balutan untuk dapat menyerap cairan yang dikeluarkan oleh luka (absorbing), kemampuan balutan untuk mengangkat jaringan nekrotik dan mengurangi resiko terjadinya kontaminasi mikroorganisme (non viable tissue removal), meningkatkan kemampuan rehidrasi luka (wound rehydration), melindungi dari kehilangan panas tubuh akibat penguapan, dan kemampuan atau potensi sebagai sarana pengangkut atau pendistribusian antibiotik ke seluruh bagian luka (Suryo, 2009)

Hasil penelitian maria (2014). Proses penyembuhan luka dengan dengan tehnik balutan wet-drybdan Moist and Wound Healing dengan hydrocoloid dressing pada penyembuhan ulkus diabetikum. Didapatkan hasil penyembuhan luka cepat sebanyak 60\% (9 responden), $33 \%$ (5 responden) dengan proses penyembuhan luka dalam waktu sedang, dan yang mengalami proses penyembuhan luka yang lambat ada 7\% (1 responden).

\section{KESIMPULAN}

Berdasarkan hasil penelitian maka dapat disimpulkan :

Perawatan luka ulkus diabetikum pada pasien diabetes mellitus dengan tehnik modern wound dressing dapat mempercepat pembentukan growth factor pada luka karena berperan pada proses penyembuhan luka untuk membentuk stratum corneum dan angiogenesis. Dimana produksi komponen akan terbentuk dalam lingkungan yang lembab sehingga mempercepat terjadinya pembentukan sel aktif, yang diikuti oleh makrofag, monosit dan limfosit ke daerah luka berfungsi lebih dini. Perawatan luka modern untuk mempertahankan dan menjaga lingkungan luka tetap lembab untuk memperbaiki proses penyembuhan luka, mempertahankan kehilangan cairan jaringan dan kematian sel dan mempercepat penyembuhan luka.

\section{SARAN}

Pemberi Pelayanan di Rumah Sakit diharapkan dalam memberikan asuhan keperawatan kepada pasien dengan luka ulkus diabetikum pada pasien diabetes mellitus, dimana perawatan luka dapat dilakukan dengan tehnik modern dressing dan meningkatkan penyembuhan luka yang lebih singkat.

\section{DAFTAR PUSTAKA}

Arikunto, S. (2010). Prosedur Penelitian. Jakarta: Rineka Cipta.

Arisanty. (2014). Konsep Dasar Manajemen Perawatan Luka. Jakarta : ECG.

Arisman. (2011). Diabetes Mellitus. Sumatera : Universitas Sumatera Utara. 
Azizah, Marifatul. (2011). Keperawatan Lanjut Usia. Yogyakarta : Graha Ilmu.

Brunner \& Suddart. (2013). Buku Ajar Keperawatan Medikal Bedah. Jakarta : EGC.

Bryant \& Nix. (2011). Acute \& Chronic Wound Current Management Concepts. USA : St. Missouri Mosby Elsevier.

Budiman. (2011). Penelitian Kesehatan. Buku pertama. Bandung: Refika Aditama.

Cardinal, Eisenbud. (2007). Eary Healing Rates and Wound Area Measurements are Reliable Predictors of Later Complete Wound Closure. http://www.ncbi.nlm.nih.gov /pubmed/18211575. diperoleh tanggal 20 febuari 2018.

Clayton \& Tom. (2009). A Review of The Pathophysiology : Clasification and Treatment of Foot Ulcer in Diabetic Patient. http://www.clinical_diabetes _mellitus/article.htm.

diperoleh tanggal 20 febuari 2018.

Corwin, J, Elisabeth, (2009). Buku Saku Patofisiologi, Edisi 3 Revisi. Jakarta: EGC.

Diani (2013). Pengetahuan Kesehatan dan Praktik Perawatan kaki pada Klien Diabetes Mellitus tipe 2 di Kalimantan. Jakarta : UI.

Efendi, Ferry. (2010). Keperawatan Kesehatan Komunitas : Teori dan Praktik dalam Keperawatan. Jakarta : Salemba Medika.

Ferawati. (2014).. Faktor-Faktor yang Mempengaruhi Terjadinya Ulkus Diabetikum Pada Pasien Diabetes Mellitus Tipe 2. Purwokerto : Unsoed.

Friedman. (2010). Family health Nursing. USA : Pearson Education Inc.

Fryberg. (2008). Diabetic Foot Disorder : A Clinical Practice
Guidline The Journal of Foot and Ankle Surgery. http://www.acfas.org/researc h-and-publications/clinicalconsensus-document/ diperoleh tanggal 20 febuari 2018.

Gabriel, Mussman. (2009). Wound Healing Growth Factors. http: / /www.demaclose.com/ document-items/educationtraining/woundtreatment/wound-healing/ diperoleh tanggal 20 febuari 2018.

Ghozali, Iman. (2009). Aplikasi Analisis Multivariate dengan Program SPSS. Semarang : Badan Penerbit Universitas Dipenogoro.

Gitarja. (2008). Perawatan Luka Terpadu Perawatan Luka Diabetes. Bogor : Wocare Publishing.

Grim, P.S. (2009). Hyperbaric Oxygen Therapie. http: / /www.auraresearch.co $\mathrm{m} / \mathrm{hbo} /$ diperoleh tanggal 20 febuari 2018.

Gustaviani. (2009). Diagnosis dan Klasifikasi Diabetes Mellitusi. Jakarta : Balai Penerbit FKUI.

Haryati. (2009). Penggunaan Balutan Modern Memperbaiki Proses Penyembuhan Luka Diabetik.

Hasnah (2009). Pencegahan Penyakit Diabetes Mellitus. FIK Keperawatan UIN : Makasar. Jurnal Media Gizi Pangan, Vol. VII, Edisi 1. http://www.academia.edu/55 95120/ diperoleh tanggal 20 febuari 2018.

Hendromartono. (2009). Nefropati Diabetik. Jakarta : Balai Penerbit FKUI.

Hidayat, A. Aziz Alimul. (2009). Metode Penelitian Keperawatan Dan Teknik Analisa Data. Jakarta: Salemba Medika. 
International Diabetes Federation. (2015). Global Guideline for Type 2 Diabetes. http://www.idf.org/diabetesa tlas/update2015/ diperoleh tanggal 20 febuari 2018.

Ismail. (2009). Penggunaan Balutan Modern Memperbaiki Proses Penyembuhan Luka Diabetik. Jakarta : EGC.

Kasjono, Yasril. (2009). Teknik Sampling untuk Penelitian Kesehatan. Yogyakarta: Graha Ilmu.

Maharani. (2015). Pengaruh Tehnik Modern Dressing Terhadap Proses Penyembuhan Luka Diabetes Mellitus.

Mansjoer, Arief. (2010). Kapita Selekta Kedokteran : Jakarta : Media Aesculapius.

Mayasari. (2012). Wanita Menopause Lebih Berisiko Diabetes Mellitus.

http:/ /www.health.detik.com $/ \mathrm{read} / 2012 / 12 / 27 / 18311 / 212$ 8250/ diperoleh tanggal 20 febuari 2018.

Muhlisin \& Idarwati. (2010). Teori Self Care dari Orem dan Pendekatan Dalam Praktek Keperawatan.

Nontji. (2012). Teknik Perawatan Luka Modern dan Konvensional Terhadap Kadar Interleukin 1 dan Interleukin 6 Pasien Luka Diabetik.

Notoatmodjo. (2010). Metodologi Penelitian Kesehatan Edisi Revisi. Jakarta: Rineka Cipta.

Notoatmodjo. (2010). Pendidikan dan perilaku kesehatan. Jakarta: Rineka Cipta.

Nursalam. (2008). Konsep dan Penerapan Metodologi Penelitian IImu Keperawatan. Jakarta: Salemba Medika.

Nursalam. (2011). Konsep dan Penerapan Metodologi Penelitian IImu Keperawatan. Jakarta: Salemba Medika.
Nursalam. (2013). Konsep dan Penerapan Metodologi Penelitian Ilmu Keperawatan, Pedoman Skripsi, Tesis dan Intrumen Penelitian Keperawatan. Jakarta : Salemba Medika.

Pandelaki. (2009). Retinopati Diabetik. Jakarta : Balai Penerbit FKUI.

PERKENI. (2011). Konsensus Pengelolaan dan Pencegahan Diabetes Mellitus Tipe 2 di Indonesia.

http://scribb.com/doc/73323

977/ diperoleh tanggal 20 febuari 2018.

Peters \& Lavery. (2001). Effectiveness of The Diabetic Foot Riskclassification System Of The International Working Group On The Diabetic Foot Diabetes Care. http://www.care.diabetesjou rnals.org/content/24/8/ diperoleh tanggal 20 febuari 2018.

Pillen. (2009). Assesment of Wound Healing : Validity, Reliability and Sensitivity of Avaible Instruments.

http: //www.awma.com.au/jo urnal/1704/ diperoleh tanggal 20 febuari 2018.

Poerwanto, Angga. (2012). Mekanisme Terjadinya Gangren Pada Penderita Diabetes Mellitus. Surabaya : FK-UWK.

Price \& Wilson. (2012). Patofisiologi : Konsep Klinis Proses-Proses Penyakit. Jakarta : EGC.

Purwanti. (2013). Analisis FaktorFaktor Risiko Terjadinya Ulkus kaki pada pasien Diabtes Mellitus.

http: / / www.lib.ui.ac.id/file?f ile=digital $/ 20334094 \mathrm{kti} \%$. diperoleh tanggal 20 febuari 2018.

Rahmawati, Dwi \& Hartono. (2012). Gangguan Pernapasan Pada 
Anak ISPA. Yogyakarta: Nuhai Medika.

Ridduwan. (2014). Dasar-Dasar Statistika. Bandung : Alfabeta.

RISKESDA. (2013). Riset Kesehatan

Dasar Tahun 2013. Badan Penelitian dan pengembangan Kesehatan Kementrian Kesehatan RI Tahun 2013.

Riyanto, Agus. (2011). Aplikasi Meodologi Penelitian Kesehatan. Yogyakarta: Nuha Medika.

Rumah Sakit Umum Daerah Al-Ihsan Provinsi Jawa Barat. (2017). Profil Kesehatan Rumah Sakit Umum Daerah Al-Ihsan Provinsi Jawa Barat.

Salmani \& Hosseini. (2010). Foot Self Care In Diabetic Patient. http://www.ijdo.ssu.ac.ir/file s/data/a10331f6cb7. diperoleh tanggal 20 febuari 2018.

Sarwono, J. (2012). Metode Riset Skripsi Pendekatan Kuantitatif Menggunakan Prosedur SPSS. Jakarta: Elex Media Komputindo.

Schwartz. (2008). Intisari PrinsipPrinsip Ilmu Bedah. Jakarta : EGC.

Setiadi. (2007). Konsep dan Penulisan Riset Keperawatan. Yogyakarta : Graha Ilmu.

Sihombing. (2012). Gambaran Perawatan Kaki Dan Sensasi Sensorik Kaki Pada Pasien Diabetes Melitus Tipe 2 Di Poliklinik DM RSUD. Bandung : FIK Unpad.
Sing. (2011). Evaluation of Wound Healing.

Sjamsuhidayat. (2010). Buku Ajar Ilmu Bedah. Jakarta : EGC.

Smelter \& Bare. (2010). Buku Ajar Keperawatan Medikal Bedah. Jakarta : ECG.

Soewondo, Pradana. (2009). Ketoasidosis Diabetik. Jakarta : Balai Penerbit FKUI.

Subekti, Imam. (2009). Buku Ajar Ilmu Penyakit Dalam. Jakarta : Balai Penerbit FKUI.

Sudoyo (2009). Buku Ajar Ilmu Penyakit Dalam Ed.V Jilid I. Jakarta: Balai Penerbit FKUI. Sugiyono. (2010). Metode Penelitian Kuantitatif, Kualitatif, dan Kombinasi (Mixed Methods). Bandung: Alfabeta.

Suriadi. (2010). Manajemen Luka. Pontianak : STIKep Muhammadiyah.

Suryo. (2009). Genetika Manusia. Yogyakarta : Gadjah Mada University Press.

Tjokroprawiro. (2011). Hidup Sehat dan Bahagia Bersama Diabetes Mellitus. Surabaya : Publiser Media.

Usman, Husaini \& Akbar, Setiadi Purnomo. (2012). Pengantar Statistika. Jakarta: Bumi Aksara.

Veves, Aristidis. (2008). The Diabetic Foot. New Jersey : Hurana Press.

Waspadji. (2009). Kaki Diabetik. Jakarta : Balai Penerbit FKUI. 